\title{
Opstandingsverhale en opstandingsdogma
}

\begin{abstract}
Author:
Izak J.J. Spangenberg ${ }^{1}$

Affiliation:

${ }^{1}$ Departement of Old

Testament \& Ancient Near

Eastern Studies, University

of South Africa, South Africa

Correspondence to:

Sakkie Spangenberg

email:

spangijj@unisa.ac.za

Postal address:

PO Box 392, Pretoria 0003,

South Africa

Dates:

Received: 26 May 2010

Accepted: 17 July 2010

Published: 07 June 2011

How to cite this article: Spangenberg, I.J.J., 2011,

'Opstandingsverhale en opstandingsdogma',

HTS Teologiese Studies/

Theological Studies 67(1),

Art. \#874, 8 pages. DOI:

$10.4102 /$ hts.v67i1.874
\end{abstract}

\section{Resurrection narratives and the doctrine of resurrection}

The article examined the closing narratives of the four canonical gospels and argued that they should be read as stories and not as historical narratives. These stories, however, show a progressive development and it is evident that the narrators of the later stories embellished the earlier narratives. Christian theologians of later centuries developed these stories into a theology of salvation and linked resurrection to the idea of death being God's punishment for Original Sin. By doing so, they changed the Gospel of Jesus into the Gospel about Jesus. Currently, people have a different understanding of themselves and the world in which they live. Death is seen as part of the cycle of life and humans, like everything else, will not be resurrected but recycled. That is one of the reasons why Christianity is in dire need of a new paradigm that will take into account the real position of human beings in the cosmos.

\section{Inleiding}

Teologiese diskoerse wat in ander lande ontstaan, bereik Suid-Afrika wel een of ander tyd en het dikwels die gevolg dat mense van kettery aangekla word. Neem as voorbeeld die kwessie van die Mosaïese outeurskap van die Pentateug. Dit is in die laat twintigerjare van die vorige eeu tydens die Du Plessis-stryd op Stellenbosch op die spits gedryf (Le Roux 1986). In Brittanje en die VSA is hierdie kwessie al heelwat vroeër bespreek (Rogerson 1984:273-289; Shriver 1997). Soos die geval hier met Du Plessis was, is geleerdes ook dáár van dwaalleer aangekla. Dieselfde geld vir die Makkabeërteorie rakende die interpretasie van die boek Daniël. Hierdie teorie is in ongeveer 1890 deur Duitse Ou-Testamentici aanvaar, terwyl dit eers ná die Eerste Wêreldoorlog (1914-1918) in Brittanje en die VSA aanvaar is. In Suid-Afrika het dit eers in die sewentigerjare van die vorige eeu 'n aanvaarde teorie geword (Spangenberg 1999:592). Geen Ou-Testamentikus is egter van kettery aangekla nie, maar konserwatiewe Christene verwerp steeds die Makkabeërteorie en glo vas dat die boek 'n profetiese geskrif is wat die toekoms haarfyn voorspel - dit sluit natuurlik Jesus se kruisiging in (Spangenberg 1985).

'n Debat oor die opstanding van Jesus en hoe dit verstaan behoort te word, is reeds in die sestigerjare van die vorige eeu in Nieu-Seeland gevoer. Professor Lloyd Geering, destyds 'n OuTestamentikus aan die Knox College in Dunedin en lidmaat van die Presbiteriaanse Kerk van NieuSeeland, het onbedoeld 'n storm ontketen met die skryf van 'n artikel hieroor (Geering 2006:131146, 246-252). In Nederland is die opstanding in die laat tagtigerjare van die vorige eeu dáár indringend bespreek (Baarda 1991; Van Gennep 1989). Nou, ná onderskeidelik 50 en 20 jaar, word die opstanding ' $n$ brandende teologiese kwessie in Suid-Afrika. Die liggaamlike opstanding word in sommige kringe as dié toetssteen vir regsinnigheid beskou en Bybelwetenskaplikes en teoloë wat ander standpunte hieroor huldig, beland in die spervuur en word as ketters gebrandmerk. Sommige teoloë is selfs van mening dat die Evangelie op die spel is (König 2009:236-274).

In hierdie artikel word eerstens gekyk na die opstandingsverhale in die vier kanonieke evangelies ten einde te bepaal wat uniek aan elke verteller se verhaal is. Daarná word die meesterverhaal van die Westerse Christendom ondersoek en word verduidelik waarom opstanding in hiérdie verhaal so belangrik is. Laastens word enkele opmerkings gemaak oor waarom sommige Christene tans die dogma van 'n liggaamlike opstanding verwerp, maar wel iets met die verhale wil doen.

Ek dra die artikel graag aan Andries van Aarde op, wat met sy boek Fatherless in Galilee (2001) my belangstelling in die sinoptiese evangelies, die Q-spreuke-evangelie, die Tomas-evangelie en die navorsing oor die historiese Jesus aangewakker het.

\section{Die vier evangelies en hul onderskeie opstandingsverhale}

In my bespreking van die sinoptiese evangelies se opstandingsverhale gebruik ek die Tweebronneteorie as vertrekpunt omdat dit die samehang tussen dié evangelies die beste verduidelik en verantwoord (Kloppenborg 2008:1-40; Walters 2010:243). Ek aanvaar voorts dat die Markus- 
evangelie in ongeveer $70 \mathrm{nC}$ geskryf is; die Matteus-evangelie tussen 80 en $90 \mathrm{nC}$ en die Lukas-evangelie eweneens tussen 80 en $90 \mathrm{nC}$. Die Johannes-evangelie is laat geskryf en 'n datum tussen 90 en 110 nC lyk die waarskynlikste. Daar is verskeie navorsers wat hierdie daterings voorstaan en onderskryf. Ten opsigte van Markus is daar Burkett (2002:157), Schnelle (1998:200-202), Schröter (2010:277-279) en Theissen (2003:96). Ten opsigte van Matteus is daar Beeching (1997:66), Duling (2010:298-299) en Schnelle (1998:222). Sommige geleerdes reken dat die skrywer van die Matteus-evangelie onder andere reageer op die ontwikkelinge in die ontluikende posttempel-Judaïsme en dat hy Jesus se boodskap voorhou as 'n ewe legitieme uitdrukking van Judaïsme (Kee 1997:501503, Theissen 2003:105-107; Trocmé 1997:88-90; Vermes 2001:218). Matteus se Jesus staan nie teenoor die Wet nie, maar bly daaraan getrou en verwag van sy volgelinge om ook daaraan getrou te bly. Wat die Lukas-evangelie betref, reken die volgende geleerdes dat dit tussen 80 en $90 \mathrm{nC}$ geskryf is: Burkett (2002:196), Schnelle (1998:243), Stanton (2002:95), Thompson (2010:331) en Trocmé (1997:91). Die volgende geleerdes kan as verteenwoordigers voorgehou word van diegene wat die Johannes-evangelie teen die einde van die eerste eeu of vroeg in die tweede eeu dateer: Lüdemann (2000:419), Schnelle (1998:476-477), Stanton (2002:120) en Trocmé (1997:108). Geleerdes wat hulle op die studie van die Johannes-evangelie toelê, is dit deesdae byna eens dat die evangelie nie die werk van slegs één skrywer is nie, maar 'n dokument waaraan verskeie skrywers 'n aandeel gehad het (Painter 2010:347) en voorts dat hierdie evangelie die breuk wat tussen die ontluikende posttempel-Judaïsme en die vroeë Christendom ontstaan het, duidelik weerspieël.

Naas die datering van die evangelies is die belangrikste vraag wat geen leser van die evangelies kan ontwyk nie die vraag na die literatuursoort. Met watter soort genre het ons hier te doen? Vorster het hieroor intensiewe navorsing gedoen en tot die slotsom gekom dat die skrywer van Markus 'n unieke literatuursoort geskep het wat deur die ander evangelieskrywers (met allerlei variasies) nageboots is (Vorster 1981:26-27). Die studie van die Q-Spreukeevangelie en die Tomas-evangelie het ander geleerdes weer daartoe gebring om 'n tweede genre te onderskei, naamlik spreuke-evangelies. Daar was in die vroeë Christendom klaarblyklik twee verskillende genres in omloop wat albei as 'evangelies' getipeer kan word: verhalende evangelies en spreuke-evangelies. Alhoewel die verhalende evangelies na historiese karakters verwys, voldoen dit nie aan die kriteria wat vir historiese berigte gestel word nie. Dit geld veral vir die geboorte- en die opstandingsverhale. Hierdie verhale vertoon legendariese trekke, want die verhaalfeite strook nie onderling nie.

'n Derde saak wat Bybellesers nie buite rekening kan laat nie, is die paradigmaverandering wat teen die einde van die 19de en die begin van die 20ste eeu in die Bybelwetenskappe voorgekom het (Spangenberg 1994:145-162). Hierdie verandering behels dat die Bybel aanvaar word vir wat dit is - 'n menslike kultuurproduk. Dit het nie uit die hemel geval nie en is ook nie deur God aan die skrywers ingegee nie. Noll, 'n
Amerikaanse kerkhistorikus, som dit só op: 'The Bible, however sublime, is a human book to be investigated with the standard assumptions that one brings to the discussion of all products of human culture' (1991:45). Daar is nog vele Suid-Afrikaanse gelowiges, predikante en teoloë wat in die ouer paradigma tuis is en wat selfs die fundamentalistiese weergawe daarvan aanhang. Volgens hulle is God die tydlose outeur van die Bybelboeke en is dit nie nodig om die boeke in hul onderskeie historiese kontekste te bestudeer nie. Hulle verwys na God as die auctor primarius (Spangenberg 2002:184-185) en staan afwysend teenoor die siening dat die Bybelboeke menslike produkte is wat soos gewone literatuur bestudeer kan word.

Barr (1973), Deist (1979), Den Heyer (1988) en Kraus (1969) het my tot die nuwe paradigma 'bekeer', daarom aanvaar ek dat die evangelies menslike geskrifte is en dat elke skrywer vir 'n spesifieke gehoor en met 'n spesifieke doel geskryf het. Voorts aanvaar ek dat wanneer 'n mens die evangelies goed wil verstaan, narratiewe ontleding deel van hierdie verstaansproses behoort te wees. Die eindresultaat van hierdie soort ontleding is dat elke evangelieskrywer 'n ander plot nastreef en 'n ander Jesus-karakter aan lesers voorhou. Geen twee evangelieskrywers se Jesus-karakter lyk presies dieselfde nie. Hierdie karakters is nie gelyk te stel aan die Jesus Christus van die kerklike dogmas óf die historiese Jesus van die ouer of resente Jesus-ondersoek nie (Carroll 1991:28). Dit is wel so dat geleerdes deur middel van historiese studies van die evangelies en ander bronne by die historiese Jesus probeer uitkom, maar die Jesus-karakter van die Matteus-/Markus-/Lukas-/Johannes-evangelie is nie die historiese Jesus nie. Ons kan ook nie 'n 'optelsom' van die karaktertrekke van die verskillende Jesus-karakters maak en dit as die karaktertrekke van die historiese Jesus voorhou nie. Ons kan ook nie 'n 'opstelsom' van al die Jesusuitsprake maak en dit as uitsprake van die historiese Jesus voorhou nie. Die sogenaamde sewe kruiswoorde van Jesus waaraan soveel betekenis geheg word, val in hierdie soort kategoriefout. Dit geld ook vir die verwewing van Matteus en Lukas se geboorteverhale tydens Kersfeesvieringe en die verwewing van die vier evangelies se lydensverhale tydens Paastyd. Jesus Christus van die kerklike dogmas is eweneens 'n andersoortige karakter as die Jesus-karakters van die evangelies en die historiese Jesus.

Met die voorafgaande as agtergrond kyk ek kortliks na die slotverhale van die evangelies om sodoende 'n indruk te kry van wat elke verteller met sy slotvertelling wou bereik. Dit is in hierdie slotverhale dat ons met die opstandingsverskynings te doen kry. Ek neem as vertrekpunt die volgende stelling van Fokkelman (1999) rakende die verteller van 'n verhaal:

Whoever writes a story establishes himself as the narrator, choosing the position of narrator. What does that mean? The narrator draws those lines and selects those details, right down to the smallest, that suit him. He is the boss of the complete circus. [...] He structures time, sketches space, brings characters on and takes them off again, misleads the reader at times, and enforces his point of view through thick and thin.

(Fokkelman 1999:55) 
TABEL 1: 'n Sinopsis van die ooreenkomste en verskille in die verhale.

\begin{tabular}{|c|c|c|c|}
\hline Markus & Matteus & Lukas & Johannes \\
\hline $\begin{array}{l}\text { Maria Magdalena, Maria die moeder van } \\
\text { Jakobus en Salome. }\end{array}$ & Maria Magdalena en ander Maria. & $\begin{array}{l}\text { Maria Magdalena, Johanna, Maria die moeder } \\
\text { van Jakobus en ander vroue. }\end{array}$ & Maria Magdalena by die graf. \\
\hline Reukolie & Geen reukolie & Reukolie & Geen reukolie \\
\hline- & [Aardbewing] & - & - \\
\hline $\begin{array}{l}\text { Klip voor ingang verwyder. } \\
\text { Een jongman. } \\
\text { Jesus weg. } \\
\text { Dissipels moet na Galilea gaan. }\end{array}$ & $\begin{array}{l}\text { Klip deur'n engel uit die hemel weggerol. } \\
\text { Hy vertel hulle dat Jesus weg is. } \\
\text { Dissipels moet na Galilea gaan. }\end{array}$ & $\begin{array}{l}\text { Klip weggerol. } \\
\text { Twee mans met blink klere. } \\
\text { Hulle herinner vroue aan Jesus se woorde. }\end{array}$ & Klip weggerol. \\
\hline \multirow[t]{2}{*}{-} & [Wagte word flou.] & - & - \\
\hline & & & $\begin{array}{l}\text { [Maria Magdalena lewer verslag aan } \\
\text { Petrus en die 'ander dissipel': Jesus se } \\
\text { liggaam nie in graf nie.] }\end{array}$ \\
\hline $\begin{array}{l}\text { [Vroue beangs, hardloop verskrik weg en } \\
\text { vertel niemand nie.] }\end{array}$ & $\begin{array}{l}\text { Vroue bevrees, maar bly daar - hardloop na } \\
\text { dissipels om verslag te lewer. }\end{array}$ & $\begin{array}{l}\text { Vroue hardloop na dissipels en doen verslag. } \\
\text { Niemand glo hulle nie! }\end{array}$ & - \\
\hline- & $\begin{array}{l}\text { [Jesus verskyn aan vroue. Herhaal opdrag van } \\
\text { engel.] }\end{array}$ & - & - \\
\hline- & - & $\begin{array}{l}\text { [Twee dissipels op pad na Emmaus. Jesus sluit } \\
\text { by hulle aan. Verduidelik Skrifte. Verlaat hulle en } \\
\text { verskyn aan Petrus.] }\end{array}$ & - \\
\hline- & - & - & $\begin{array}{l}\text { [Petrus en die 'ander dissipel' na graf. } \\
\text { Die 'ander dissipel' glo. Albei keer } \\
\text { terug.] }\end{array}$ \\
\hline- & Vroue lewer verslag aan dissipels. & - & - \\
\hline- & - & - & $\begin{array}{l}\text { Maria Magdalena sien twee engele. } \\
\text { Vra na Jesus se liggaam. }\end{array}$ \\
\hline- & $\begin{array}{l}\text { [Wagte vertel priesters. Hul opdrag: Vertel 'n } \\
\text { leuen!] }\end{array}$ & - & - \\
\hline- & - & - & $\begin{array}{l}\text { [Maria Magdalena sien 'n tuinier, maar } \\
\text { dis toe Jesus.Sy opdrag: Vertel dissipels } \\
\text { Hy is op pad na sy God.] }\end{array}$ \\
\hline- & - & $\begin{array}{l}\text { Verskyn aan dissipels in Jerusalem. Hulle dink } \\
\text { Hy is'n gees. } \\
\text { Hulle raak aan Hom. } \\
\text { Hy eet vis. } \\
\text { Jesus verduidelik die Skrifte. }\end{array}$ & Verskyn aan dissipels in Jerusalem. \\
\hline - & - & $\begin{array}{l}\text { Opdrag en Heilige Gees. } \\
\text { Bly in Jerusalem. }\end{array}$ & Opdrag en Heilige Gees in Jerusalem. \\
\hline- & - & - & [Tomas afwesig.] \\
\hline- & - & - & [Tomas teenwoordig.] \\
\hline \multirow[t]{2}{*}{-} & $\begin{array}{l}\text { Verskyn aan dissipels [op 'n berg] in Galilea. } \\
\text { Aanbidding en twyfel. }\end{array}$ & - & $\begin{array}{l}\text { See van Galilea. } \\
\text { Jesus staan ligdag op strand - niemand } \\
\text { herken Hom nie. }\end{array}$ \\
\hline & Opdrag en belofte. & & Petrus word herstel. \\
\hline
\end{tabular}

Gegewe die lengtebeperking van die artikel is dit nie moontlik om in detail aan al die aspekte van narratiewe ontleding aandag te gee nie. Slegs enkele aspekte word aangeroer. Om dit moontlik te maak en om die verskille tussen die verhale vinnig raak te sien, gee ek 'n kort opsomming in tabelvorm hier bo weer. Dis 'n verwerking van 'n tabel wat Vermes in sy boek The resurrection (2008:113-114) verskaf.

\section{Die ooreenkomste en verskille in die verhale}

\section{Markus 16:1-8}

Die oudste kopieë van die Markus-evangelie waaroor ons beskik, eindig met Markus 16:8 (Schröter 2010:279; Thierry 1982:39; Vermes 2008:101). Markus 8:9-20 is later toegevoeg om hierdie evangelie se abrupte slot in lyn te bring met die ander evangelies. Vir die doel van hierdie bespreking laat ek die langer slot buite rekening.
Volgens die verteller het daar vier dinge ná Jesus se begrafnis gebeur:

1. Drie vroue het ná die Sabbat reukolie gaan koop om sy liggaam daarmee te balsem.

2. Hulle arriveer die Sondagmôre met sonsopkoms by die graf en vind dat die klip weggerol is.

3. Toe hulle in die graf ingaan, sien hulle 'n jongman met lang wit klere. Hy deel hulle mee dat Jesus uit die dood opgewek is, dat Hy vooruit is na Galilea en dat hulle die nuus aan sy dissipels moet gaan meedeel.

4. Die vroue skrik hulle asvaal, vlug uit die graf en deel aan niemand die nuus mee nie omdat hulle bang was.

Die verteller swyg in duisend tale oor herverskynings. Daar is slegs maar die woorde van die jongman dat Jesus op pad is na Galilea en dat Hy daar te sien sal wees. Die woorde van die jongman (wat na regte die verteller se eie woorde is) dwing lesers om te besin oor hul eie reaksie op Jesus se verkondiging van die koninkryk. Suggit (1997:36) stel dit 
mooi: 'Mark leaves his readers to draw their own conclusions. How will they respond to the story which Mark has told?'

\section{Matteus 28:1-20}

Volgens die verteller van die Matteus-evangelie is slegs twee vroue die Sondagmôre graf toe. Hulle was Maria Magdalena en 'die ander Maria'. Daar word nie gewag gemaak van reukolie vir die balseming van 'n lyk nie. Die vroue gaan bloot net om na die graf te gaan $k y k$. Die verseëlde graf het as't ware vir hierdie blik van die vroue gewag, want met hul aankoms is daar skielik 'n geweldige aardbewing. 'n Engel het uit die hemel gekom, die klip weggerol en daarop gaan sit. Hierdie verskyning en gebeure het die soldate voor die graf laat flou val. Die volgende drie verse (Matt 28:5-7) stem grootliks ooreen met Markus se weergawe, maar wat die jongman in Markus aan die vroue te sê gehad het (Mark 16:67 ), sê die engel nou. Nog 'n verskil wat opval, is dat die vroue die dissipels wél gaan inlig. Vóór hulle egter twee tree weg van die graf kon gee, staan Jesus by hulle. Die verskyning dwing hulle tot aanbidding (Matt 28:9). Jesus herhaal dan die boodskap van die engel: 'Gaan vertel my broers ...'.

Die verteller neem die leser dan skielik in 'n ander rigting terwyl die vroue na die dissipels gaan. Die leser kom saam met die soldate by die priesters in Jerusalem aan. Die leser hoor hoe hulle die nuusgebeure aan die priesters meedeel en hoe die twee groepe onderling saamsweer om 'n leuen die wêreld in te stuur. Dan volg daar vertellerskommentaar: 'Hierdie storie word tot vandag toe onder die Jode verder vertel' (Matt 28:15b). Hierdie kommentaar slaan op die tyd toe die evangelie geskryf is en latere lesers van die evangelie kan nie die aanname maak dat Jode steeds hierdie verhaal versprei nie.

Die slottoneel van die evangelie speel op ' $n$ berg in Galilea af (Matt 28:16-20). Waarom 'n berg? Die verteller van die Matteus-evangelie teken Jesus as ' $n$ tweede Moses (Spangenberg 2009:251-267) en daarom sluit sy Jesuskarakter sy lewe af soos Moses syne op 'n berg afgesluit het (Deut 34:1). Die dissipels reageer egter nie eenvormig op Jesus se verskyning nie. Sommige aanbid Hom terwyl ander twyfel. Dan reageer Jesus met 'n stelling, 'n drievoudige opdrag en weer 'n stelling. Die drievoudige opdrag behels:

- gaan maak dissipels

- doop hulle

- 'leer hulle om alles te onderhou wat Ek julle beveel het'.

Hierdie laaste woorde is veral belangrik. Vra 'n mens na wat Jesus die dissipels 'beveel het', staan dit soos 'n paal bo water dat dit verband hou met Jesus se lering oor die Wet. Die Wet bly steeds van krag en moet met wysheid en insig uitgeleef word (Matt 5:19-20; 7:21-23). Die Christengroep vir wie hierdie evangelie geskryf was, word as Joodse Christene getipeer. Hulle het hul identifisering met Jesus as net so 'n legitieme uitdrukking van hul Joodsheid beskou as die ander Jode wat hul gewig agter die ontluikende posttempelJudaïsme ingegooi het. Die slotstelling 'Ek is met julle ...' (Matt 28:20) gryp terug na die verskyning van die engel aan
Josef voor Jesus se geboorte en die naam 'Emmanuel', wat 'God met ons' beteken (Matt 1:23).

In die voorafgaande tabel is die unieke materiaal van die Matteus-verteller in vierkantige hakkies geplaas (dit geld ook die unieke materiaal van die ander evangelies). Uit die tabel behoort dit duidelik te wees dat hierdie verteller homself groter vryheid veroorloof het as die Markus-verteller. Ons het hier duidelik met legendariese materiaal te doen. 'n Aardbewing lei die gebeure in en 'n engel uit die hemel verskuif die rots voor die grafopening. Daar is Romeinse wagte en priesters met wie subtiel die spot gedryf word. Jesus verskyn nou aan mense - maar dit is kortstondige verskynings en slegs aan sy volgelinge. Van 'n hemelvaart is hier nie sprake nie - maar van 'n konstante teenwoordigheid wel: 'Ek is met julle al die dae tot die voleinding van die wêreld' (Matt 28:20). Hierdie woorde suggereer dat die verteller die einde binnekort verwag het. Die einde is nie iets wat in die verre toekoms lê nie. Dis om die draai!

Die Lukas-evangelie se slot is nie net aansienlik langer en anders as Markus s'n nie, dis ook langer en anders as Matteus $s^{\prime} n$. Dit bestaan uit vier tonele. Die eerste toneel speel by die graf af (Luk 24:1-12). Meer as drie vroue het die Sondagoggend met reukolie na die graf gegaan. Dáár ontdek hulle dat die graf leeg is. Terwyl hulle verbluf rondstaan, verskyn twee mans met blink klere op die toneel. Nadat die mans hulle aan Jesus se woorde rakende sy kruisiging en opstanding herinner het, sit hulle af na die 11 dissipels en deel hulle die nuus mee. Geeneen het die nuus geglo nie, behalwe Petrus. Hy hardloop alleen graf toe en vind dit soos die vroue dit beskryf het. Dit het hom met verwondering gelaat. Van die inligting in hierdie eerste toneel het die skrywer duidelik aan Markus ontleen, maar dit met sy eie materiaal verweef vandaar die verskille.

Die tweede toneel speel af op pad na die dorpie Emmaus, 12 $\mathrm{km}$ vanaf Jerusalem (Luk 25:13-35). Twee dissipels was op reis soontoe toe 'n vreemdeling by hulle aansluit. Die verteller deel die leser mee dat dit Jesus is en sodoende beskik die leser oor meer inligting as die karakters in die verhaal. Dis 'n interessante verteltegniek en só ' $n$ soort verteller wat buite die verhaal staan, word 'n heterodiëgetiese verteller genoem (Marguerat \& Bourquin 1999:25-27).

Die dissipels was besig om oor die afgelope paar dae se gebeure te besin. Die reisiger tree met hulle in gesprek, maar lê ook vir hulle die Skrifte uit sodat hulle tot insig kon kom. Hy het 'by Moses en al die profete begin en al die Skrifuitsprake wat op Hom betrekking het, vir hulle uitgelê' (Luk 24:27). Met hierdie opmerking word lesers op hul beurt die oningeligtes. Hulle weet nie watter Skrifgedeeltes Jesus uitgelê het nie, maar die twee dissipels weet dit wel. Die dissipels sit met gepriviligieerde inligting! Wanneer hulle by die huis aankom, maak die reisiger of Hy die reis wil voortsit. Soos goeie Jode betaam, nooi hulle Hom om oor te bly: 'Bly by ons, want dit is amper nag en die dag is al verby' (Luk 24:29). Tydens die aandete wanneer Jesus die brood breek, herken hulle Hom, maar dan verdwyn Hy skielik (Luk 24:30-31). 
Dit laat hulle onmiddellik die terugreis aanpak om die ander dissipels te gaan vertel. Daar aangekom, word die wind uit hul seile gehaal wanneer hulle begroet word met die woorde: 'Jesus het aan Petrus verskyn!' (Luk 24:34). Maar dan staan Jesus skielik in hul midde. Só breek die derde toneel aan (Luk 24:36-49)

Hier in die huis laat Hy toe dat die teenwoordiges aan Hom vat en eet Hy ook in hul teenwoordigheid vis sodat hulle oortuig kon word dat Hy nie 'n gees is nie. Vir'n tweede keer lê Hy die Skrifte uit en toon Hy aan dat die Wet, die Profete en die Psalms oor Hom geskryf het. Daarna wys Hy daarop dat die Christus moes ly en op die derde dag uit die dood moes opstaan. Voorts dat in sy Naam bekering en vergifnis van sondes aan al die nasies verkondig moet word. Hy doen 'n beroep op hulle om in Jerusalem te bly totdat hulle die gawe van God ontvang het.

In die slottoneel (Luk 24:50-53) reis almal die nag na Betanië net buite Jerusalem, waar Jesus finaal van hulle afskeid neem en hemelwaarts vertrek. Daarna keer hulle na Jerusalem terug en besoek hulle die tempel, gereeld om God te prys. Die hemelvaart vind in hierdie evangelie op dieselfde dag as die opstanding plaas - volgens die Joodse dagrekening egter die volgende dag, want dit is reeds aand, dit wil sê die begin van die volgende dag. In Handelinge vind die hemelvaart eers 40 dae ná die opstanding plaas (Hand 1:3).

Wat Lukas se vertelling betref, is daar vyf belangrike sake om van kennis te neem:

1. Al vier tonele speel naby en in Jerusalem af. Daar is geen sprake van 'n rendezvous in Galilea nie.

2. Wanneer Jesus aan die dissipels verskyn, herken hulle Hom nie onmiddellik nie. Dit geld vir sowel die twee wat na Emmaus gereis het as die groep in die huis in Jerusalem. Hierdie groep het aanvanklik gereken dat dit 'n gees is.

3. Jesus se liggaamlikheid word beklemtoon deurdat Hy eet. Vir die verteller was hierdie inligting belangrik, moontlik omdat die lesers opstanding as ' $n$ vreemde idee beleef het.

4. Ná sy opstanding lê Jesus telkens die Skrifte uit, maar die spesifieke tekste wat Hy hanteer, bly onvermeld. Die lesers word daaroor in die duister gelaat.

5. Die boodskap wat die dissipels moet verkondig, is nie die kerklike boodskap van versoening deur Jesus se kruisdood nie, maar 'bekering en vergifnis van sonde' (Luk 24:47).

Enigeen wat die Lukas-evangelie intensief bestudeer, sal weet dat vergifnis vir hom belangrik is, maar dit is nie vergifnis wat verband hou met 'n menslike offer nie (Beeching 1997:105). Vir hierdie skrywer is die kruis allermins 'n offergebeure daarom besoek Jesus se volgelinge ná sy hemelvaart steeds die tempel! Alhoewel die lesers van die evangelie moontlik nie-Jode was, bly die Judaïsme van hul Heer en Meester vir hulle belangrik.

\section{Johannes 20:1-21:25}

Die Johannes-evangelie se slot is die langste van al die kanonieke evangelies en beslaan twee hoofstukke. Johannes
20:1-31 bevat drie tonele terwyl Johannes 21:1-25 slegs één toneel bevat. Laasgenoemde is die aangrypende verhaal van Jesus se verskyning by die see van Galilea en Petrus se diepe berou.

Soos die ander evangelies, open die slothoofstuk met Maria Magdalena se besoek aan die graf (Joh 20:1-10). Hierdie keer is sy stoksielalleen en wanneer sy die graf oopgemaak en leeg vind, hardloop sy onmiddellik na Petrus en die 'ander dissipel'. Hulle sit ook af na die graf en hardloop eintlik resies om eerste daar te wees. Die 'ander dissipel' is die beter atleet en kom eerste by die graf aan, maar huiwer om in te gaan. Wanneer Petrus aankom, gaan hy onmiddellik in en sien die lyksdoeke. Albei is uit die veld geslaan, maar die 'ander dissipel' het wel geglo (Joh 20:8). Hulle is hierná huis toe en laat Maria weer stoksielalleen agter.

In die tweede toneel (Joh 20:11-18) kyk die wenende Maria in die graf en sien twee engele. (Sou Petrus en die 'ander dissipel' hulle misgekyk het?) Hulle vra haar uit na die rede waarom sy huil. Haar antwoord? 'Omdat hulle my Here weggeneem het en ek nie weet waar hulle Hom nou begrawe het nie' (Joh 20:13). Met die omdraaislag sien sy Jesus, maar besef dit nie, want sy reken dat dit die tuinier is! Dan spreek Jesus haar op haar naam aan: 'Maria' en die lig breek vir haar deur. Sy wil hom aanraak (omhels?), maar Jesus verhinder haar met die woorde dat dit nie gepas is nie. Hy het immers nog nie opgevaar nie. ('n Vreemde en onverstaanbare uitspraak!) Maria ontvang dan die opdrag om die nuus aan die res te gaan meedeel en vir hulle te sê: 'Ek vaar op na my Vader, wat ook julle Vader is, na my God, wat ook julle God is'. Telkens wanneer ek hierdie woorde lees, lui Rut se woorde aan Naomi in my kop: 'want waar u gaan, sal ek gaan; waar u bly, sal ek bly; $u$ volk is my volk; $u$ God is my God' (Rut 1:16). Sou dit wees dat die skrywer hier wél op die Rut-verhaal sinspeel en daarmee te kenne gee dat skeidslyne tussen mense onsinnig geword het? 'n Saak wat narratiewe ontleding onderstreep en wat lesers altyd in gedagte behoort te onthou, is dat geen twee lesers se weg deur ' $n$ teks dieselfde is nie (Marguerat \& Bourquin 1999:141), daarom sal daar altyd onderlinge verskille in die verstaan van die evangelies voorkom.

Die derde toneel (Joh 20:19-29) speel in Jerusalem af waar al die dissipels (met uitsondering van Tomas) teenwoordig is. Jesus verskyn skielik aan hulle en toon aan hulle sy hande en voete - sigbare tekens van sy sterwe aan die kruis. Dan stuur Hy hulle soos die Vader Hom gestuur het en blaas op hulle sodat hulle die Heilige Gees kan ontvang. Vir 'n tweede keer maak Jesus 'n vreemde uitspraak: As hulle ander mense hul sondes vergewe, sal God dit vergewe, maar die omgekeerde geld ook. Indien hulle ander mense hul sondes nie vergewe nie, sal God dit ook nie vergewe nie (Joh 20:23). Die dissipels vertel die nuus aan Tomas, maar hy reageer met twyfel. Hy wil sien en tas voordat hy sal glo (Joh 20:25).

Die tweede afdeling van hierdie toneel speel 'n week later af en soos die verteller dit wil hê, is Tomas teenwoordig. Jesus verskyn dan weer terwyl almal agter toe deure vir die Jode wegkruip. Jesus rig dan 'n uitnodiging aan Tomas om die 
dade wat hy graag wou verrig wel te kom verrig: 'Bring jou vinger hier en kyk na my hande; en bring jou hand en steek hom in my sy; en moenie langer ongelowig wees nie maar wees gelowig' (Joh 20:27). Tomas is totaal verleë en reageer met: 'My Here en my God!' Die daaropvolgende Jesuswoorde is na regte nie net aan Tomas gerig nie, maar ook aan die lesers van die evangelie: 'Gelukkig is dié wat nie gesien het nie en tog glo' (Joh 20:29).

Die verteller sluit sy verhaal af met die stelling dat daar nog baie te vertel is, maar dat dit wat wél vertel is, 'n doel dien: Mense behoort hierná te kan glo dat Jesus die Messias, die Seun van God is en dat hulle deur in Hom te glo, die lewe kan hê.

Hierná volg nog 'n verhaal oor 'n verskyning by die see van Galilea (Joh 21:1-25). Soos Maria vroeër, het die dissipels Hom nie onmiddellik herken nie. Dis eers wanneer hulle sy opdrag uitvoer en 'n net vol visse aan wal bring dat hulle Hom herken. Nadat hulle 'n maaltyd saam geniet het, spreek Jesus Petrus drie keer aan. ('n Herinnering aan die verraad van 'n paar dae tevore.) Dit lei tot selfinsig, bekering en aanvaarding van sy rol as volgeling (Joh 21:19). Ook in hierdie geval sluit die toneel af met die verteller wat die leser meedeel dat daar nog baie dinge te vertel is. Maar hiermee moet volstaan word. Hierdie slotverhaal kan as bewys dien dat meer as een skrywer aan die evangelie van Johannes geskryf het. Een slot was nie genoegsaam nie.

\section{Drie teenoor een, of twee-twee?}

Ons het gewoond geraak daaraan om die sinoptiese evangelies en die Johannes-evangelie afsonderlik van mekaar te interpreteer. Wanneer ' $n$ mens egter na die slotverhale in die bostaande tabel kyk, is daar ' $n$ duidelike toename op te merk in die lengte van die slotverhale. Verder is daar ook interessante ooreenstemmings tussen die Markus- en die Matteus-evangelie aan die een kant en die Lukas- en die Johannes-evangelie aan die ander kant. 'n Mens kan na regte 'n skeidslyn in die tabel trek om die vier evangelies in twee kategorieë te verdeel. Die twee evangelies aan die regterhand (Lukas en Johannes) se slotverhale is aansienlik langer as die twee aan die linkerhand (Markus en Matteus). Voorts kry ons hier vir die eerste keer met verhale te doen waarin daar klem gelê word daarop dat Jesus met 'n werklike menslike liggaam aan die dissipels verskyn het. Dit kom by sowel die Lukas- as die Johannes-evangelie voor. Maar dan is daar 'n eienaardigheid. Wanneer Jesus wél liggaamlik verskyn, herken gééneen van sy volgelinge Hom onmiddellik nié. Vergelyk die verskyning aan die twee dissipels op pad na Emmaus (Luk 24:15-16) en die verskyning aan die dissipels in Jerusalem (Luk 24:36-37) in soverre dit die Lukas-evangelie betref. Vergelyk ook die verskyning aan Maria by die graf (Joh 20:14-16) en die verskyning aan die dissipels by die see van Galilea (Joh 21:4-7) in soverre dit die Johannes-evangelie betref. Wat die vertellers van hierdie evangelies suggereer, is dat die verskynings nie so evident is nie. Daarom lees ons van Tomas se twyfel in die Johannes-evangelie en die oproep om te glo sonder om te wil sien en tas. Wat duidelik uit die verhale blyk, is die vryheid wat die verteller het om sy Jesus-karakter te laat doen wat hy wil hê Hy moet doen. As sy Jesus-karakter langs die see van Galilea moet staan, dan staan Hy daar en kyk toe wat die dissipels doen (Joh 21:4). As hy wil hê sy Jesus-karakter moet op 'n berg in Galilea afskeid neem, dan neem sy Jesus daar afskeid (Matt 28:16-17). As hy wil hê sy Jesus-karakter moet vuur maak, vis en brood bak en dit saam met die dissipels eet, dan doen sy Jesus-karakter dit (Joh 21:9, 12-13). Hierdie is nie historiese beskrywings nie, maar kreatiewe inkledings van die herverskyningsverhale.

Teenoor die twee evangelies wat van liggaamlike verskynings (wat duidelik nie klinkklaar is nie) vertel, staan Markus met géén verskyningsverhaal nie en Matteus wat Markus se inligting oorneem en dit ombou tot twee kort verskynings (Matt 28:1-10, 16-20). In die eerste verhaal is die vroue nie meer verskrik nie, maar nou 'bang maar baie bly' (Matt 28:8). In die tweede verhaal wat op ' $n$ berg in Galilea afspeel, deel die verteller die leser mee dat van die dissipels getwyfel het en onseker was of dit wél Jesus was wat aan hulle verskyn het (Matt 28:17). Was dit nie dalk Moses of Elia gewees nie? Hulle het immers vroeër hul verskynings gemaak (Matt 17:1-8).

Gegewe dié feite kan 'n mens tereg vra of die aanspraak van sommige teoloë dat alle Christene deur die eeue Jesus se letterlike en liggaamlike opstanding aanvaar en bely het, en dat alle Christene tans dit só moet aanvaar en bely, geregverdig is. Na my mening vertel die verhale, soos hierbo uitgewys, 'n ander storie. Afgesien daarvan dat daar vier verskillende verhale bestaan oor wat by die graf afgespeel het, weerspieël van die verhale onsekerheid en twyfel. Nie al die karakters aanvaar dat dit wél Jesus is wat aan hulle verskyn nie.

Na my mening is daar egter 'n ander rede vir die aandrang dat alle Christene die letterlike en fisiese opstanding van Jesus moet bely. Dit word egter nie in die gesprekke en debatte op tafel gesit nie, maar verswyg. Dis naamlik die kerklike leer wat voorhou dat alle mense sterf vanweë Adam (en Eva) se ongehoorsaamheid. Geloof in Jesus (die tweede Adam) se kruisiging en opstanding maak hierdie ongehoorsaamheid ongedaan, red mense van die dood en waarborg hulle 'n plek in die hemel. Hieraan gee ek kortliks aandag in die volgende afdeling.

\section{Die meesterverhaal van die Westerse Christendom}

Nêrens in die sinoptiese evangelies vind ons enige aanduiding dat Jesus een of ander verlossingsbetekenis aan sy kruisiging en opstanding toesê nie. In die drie voorspellings in die Markus-evangelie laat die verteller Jesus net sê dat die 'Seun van die mens' binnekort gaan ly, sterf en opstaan (Mark 8:31; 9:31; 10:33-34). Dit word as feite gestel, maar géén teologie word daarom gebou en géén dieper boodskap word daaraan geheg nie. Dit blyk onder andere duidelik wanneer 'n mens die slotverhale van die Matteus-, Lukasen Johannes-evangelie lees. Daar word slegs maar vertel dat Jesus gekruisig is en dat Hy nádoods aan van sy volgelinge 
verskyn het en hulle 'n opdrag gegee en toegerus het. Paulus bou egter' $n$ hele teologie om die kruisiging en opstanding. $\mathrm{Na}$ regte kan 'n mens sê dat Paulus 'n nuwe evangelie op tafel sit (Luttikhuizen 2006:19,63-76). Sy evangelie behels dat Jesus se kruisdood en opstanding dit vir nie-Jode moontlik maak om sonder besnydenis, dieetvoorskrifte en Sabbatviering deel van God se uitverkore volk te word. Dít werk hy omvattend in die Romeine-brief uit (Spangenberg 2009:194-220). Wat egter vir Paulus en alle vroeë Christene ononderhandelbaar was, was die eenheid van God. In die Romeinse staatsbestel wat politeïsme onderskryf en gepropageer het, het hulle bly verkondig dat daar slegs één God is. Dit was hierdie beklemtoning van die eenheid van God en die weiering om aan die godsdienstige feeste van die Ryk deel te neem wat Christene aanvanklik die teiken van die Romeinse owerheid se gramskap gemaak het. Pauliniese Christene het hulle ook die argwaan van die Jode op die hals gehaal, want na hul oordeel het Paulus met sy boodskap die Wet gedevalueer. Christene (nie-Jode) wat Paulus se evangelie aanvaar, kan onmoontlik as deel van God se uitverkore volk (Jode) beskou word. Hulle aanvaar immers nie die identiteitsmerkers van God se uitverkore volk nie.

Paulus gebruik heelwat motiewe en karakters uit die Ou Testament om aan sy evangelie dat nie-Jode sonder wetsvoorskrifte deel van God se uitverkore volk kan word, lyf te gee. Een hiervan is om Adam teenoor Jesus (die tweede Adam) te stel (Rom 5:12-21). Adam het sonde en dood in die wêreld gebring, maar die tweede Adam (Jesus) het genade en lewe gebring. Paulus verkondig duidelik ' $n$ evangelie oor Jesus en nie meer die Evangelie van Jesus nie. Indien ons meer oor Jesus se Evangelie wil weet, moet ons die sinoptiese evangelies bestudeer. Dáár is dit duidelik dat sy Evangelie met God se heerskappy verband hou (Mark 1:14-15). Hierdie heerskappy staan teenoor die Romeinse heerskappy. Ons kan ook sê dat God se imperium teenoor die Romeinse imperium staan. Horsley (1993:121) verwoord dit treffend: 'The rule of God preached by Jesus stood in conflict with, even in judgement upon, the rule of Caesar and Herod'. Jesus se Evangelie het aan onderdrukte Jode hoop voorgehou en Jesus self het geglo dat die koninkryk binne afsienbare tyd gevestig sou word (Luttikhuizen 2006:15-16). Sy gewelddadige dood aan die kruis deur die toedoen van die amptenare van die Romeinse imperium het die hoop ' $n$ gevoelige slag toegedien. Maar van sy volgelinge het verhale van herverskynings begin vertel en so die hoop lewendig gehou. Nie alle Christene het egter Jesus se kruisdood en opstanding die fokuspunt van hul identifisering met Hom gemaak nie. Daarvan getuig die Q-Spreuke-evangelie en die Tomas-evangelie. Die diversiteit wat die vroeë Christendom gekenmerk het, sou egter met die optrede van keiser Konstantyn (275-337) en keiser Theodosius die Grote (346395) tot niet gemaak word.

Die Christen-biskoppe het Paulus se teologie gebruik om eenheid onder Christene te bewerkstellig. Hulle het met ' $n$ meesterverhaal na vore te kom wat aan die kerk geweldige mag oor mense se lewens en denke gegee het. Augustinus (354-430) was een van die belangrike argitekte van die meesterverhaal. Hy het beklemtoon dat alle mense in sonde ontvang en gebore word en onder God se toorn leef. Die breuk wat die sonde tussen God en mens veroorsaak het (só is geglo), kon slegs via Jesus se kruisdood herstel word. Mense kon alleen met God versoen word deur die kruisdood van Jesus, want Hy sterf namens hulle en in hul plek. Die kruisdood, wat 'n politieke daad was, is omgedop en herinterpreteer as 'n gebeure wat tussen God en mense afgespeel het. Met hierdie herinterpretasie is die Romeinse imperium van alle blaam vir Jesus se kruisdood onthef, en Sullivan (2002) betoog tereg as volg:

Viewing Jesus' death as a religious event (an act bringing about reconciliation between God and humankind) does not harmonize with viewing Jesus' death as a political event (the execution of a potential rebel against the Roman Empire).

(Sullivan 2002:157)

Maar dit is wat Jesus se kruisdood was - 'n politieke teregstelling. Noudat Jesus se kruisdood godsdienstig ingeklee is, moes die opstanding ook godsdienstig ingeklee word. Opstanding het Jesus se triomf oor die dood geword. Die dood was oorspronklik God se straf vir die ongehoorsaamheid van Adam en Eva, maar Jesus het die straf gedra. Weereens het Paulus se teologie oor die dood en opstanding die nodige Skriftuurlike grondslag voorsien, maar na regte het ' $n$ nuwe evangelie die lig gesien. Hierdie nuwe evangelie kan opgesom word met die woorde sondevalverlossing-eindoordeel. In die woorde van Kennedy (2006):

In sum, the three pillars of Christian's conventional account of human destiny in relation to God are the doctrines of humanity's Fall, engineered by Adam and Eve; Redemption wrought by the self-sacrificing death of Jesus Christ; and his future Judgment of the entire human race.

(Kennedy 2006:ix)

Kennedy (2006:252, 255) noem dit ook die 'Augustiniaanse paradigma' van die Christelike teologie. Dit is hierdie paradigma wat agter die aandrang lê dat Christene Jesus se opstanding as ' $n$ historiese en fisiese opstanding moet erken ten einde as Christene te kan kwalifiseer. Sonder ' $n$ fisiese opstanding is daar geen 'bewys' dat die dood oorwin is nie. Wanneer dood egter as deel van die lewensiklus op aarde geneem word en nie meer as straf vir sonde beskou word nie, het Christene ' $n$ ander paradigma vir hul teologie nodig.

\section{'n Nuwe teologiese paradigma?}

Die Augustiniaanse paradigma waarna in die vorige afdeling verwys is, het volgens Kennedy die einde van sy rakleeftyd bereik. Hy verwoord dit treffend: 'As Christianity begins its twenty-first century, its Augustinian paradigm of theology has met the fate of the Berlin Wall' (Kennedy 2006:252). Ons weet vandag dat mense nie sterf omdat twee oervoorouers God in die tuin van Eden kwaad gemaak het nie. Ons weet dat dood nie straf vir húl ongehoorsaamheid is nie - al is dit Paulus se oortuiging. Anders as Paulus weet ons tans dat dood nog altyd deel van die lewensiklus op aarde was (Eloff 1975:15).

Ons weet ook dat Jesus se kruisdood nie 'n godsdienstige gebeurtenis was nie, maar ' $n$ politieke gebeurtenis. Jesus sterf nie aan die kruis omdat God dit gewil het nie, maar omdat 
die Romeinse imperium dit gewil het. Die Romeine het kruisiging as straf vir wegloperslawe en politieke rebelle gebruik. Dit was hul verkose vorm van staatsterrorisme om mense onderhorig te hou.

Ons weet verder dat Jesus se volgelinge ná sy kruisdood verhale oor herverskynings begin vertel het as 'n wyse om die hoop op die koms van die koninkryk lewendig te hou. Hierdie verhale is onder andere vertel ter ondermyning van die Romeine se aanspraak dat die Joodse rebel (Jesus van Nasaret) dood is en dat die Romeinse staatsmag triomfeer. Die vroeë Christene het onder andere met die herverskyningsverhale beklemtoon dat nie mag nie, maar liefde triomfeer en dat mense mag bly hoop op 'n beter toekoms.

Ons weet vandag dat ons nie eendag liggaamlik gaan opstaan nie, maar dat die materie waaruit ons liggame bestaan gehersirkuleer gaan word. Dit geld nie net vir mense nie, maar vir alle lewende en nielewende dinge wat op aarde bestaan. Na regte geld dit vir alle dinge in die ganse kosmos (Gribbin 2001).

Met al hierdie kennis staan teoloë tans voor die uitdaging om met 'n nuwe teologiese paradigma na vore te kom wat vir mense van die 21ste eeu sin sal maak en hulle kan help om lewe as heilig te beskou sodat hulle met ontsag daarmee sal omgaan. Daar is verskeie teoloë wat hiermee besig is. Onder hulle tel Lloyd Geering, na wie ek aan die begin van hierdie artikel verwys het. Hy verkies om te praat van The greening of Christianity (2005). Daar is ook ander teoloë wat hieraan meewerk. Onder hulle beklee Anne Primavesi 'n belangrike plek. In haar boek Sacred Gaia (2000) keer sy die tradisionele teologie waarin die mens die sentrale plek beklee die rug en ontwikkel sy 'n teologie wat fokus op die aarde en alles wat daarop geleef het en steeds leef. Wie uiteindelik besef dat die mens nie die spilpunt van die heelal is nie, neem met gemak afskeid van die Augustiniaanse paradigma van die teologie en die verletterliking en verdogmatisering van alles wat in die Bybel geskryf staan - en dit sluit die idee van 'n liggaamlike opstanding in.

\section{Literatuurverwysings}

Baarda, T., 1991, “'Als Christus niet is opgewekt ..." Het Nieuwe Testament in het "Geding"', Kerk en Theologie 42, 305-316.

Barr, J., 1973, The Bible in the modern world, SCM, London.

Beeching, P.Q., 1997, Awkward reverence: Reading the New Testament today, SCM, London.

Burkett, D., 2002, An introduction to the New Testament and the origins of Christianity Cambridge University Press, Cambridge.

Carroll, R.P., 1991, Wolf in the sheepfold: The Bible as a problem for Christianity, SPCK London.

Deist, F.E., 1979, Historiese heuristiek, teologiese hermeneutiek en Skrifgesag, Universiteit van Port Elizabeth, Port Elizabeth.

Den Heyer, C.J., 1988, De oude Bijbel in een moderne wereld, Kok, Kampen.

Duling, D.C., 2010, 'The gospel of Matthew', in D.E. Aune (ed.), The Blackwell companion to the New Testament, pp. 296-318, Wiley-Blackwell, Chichester. companion to the New Testament,
doi:10.1002/9781444318937.ch18

Eloff, J.N., 1975, 'Die dilemma van die moderne Christenbioloog', Intreerede 06 Mei 1975, UOVS, Bloemfontein.

Fokkelman, J.P., 1999, Reading Biblical narrative: A practical guide, Deo Publishing, Leiderdorp.
Geering, L., 2005, The greening of Christianity, St Andrew's Trust for the Study of Religion and Society, Wellington.

Geering, L., 2006, Wrestling with God: The story of my life, Imprint Academic, Exeter.

Gribbin, J., 2001, Stardust: The cosmic recycling of stars, planets and people, Penguin, London.

Horsley, R.A., 1993, The liberation of Christmas: The infancy narratives in social context, Continuum, New York.

Kee, H.C., 1997, 'The formation of the Christian community', in H.C. Kee, E.M. Meyers, J. Rogerson \& A.J. Saldarini (eds.), The Cambridge companion to the Bible, pp. 441-583, Cambridge University Press, Cambridge.

Kennedy, P., 2006, A modern introduction to theology: New questions for old beliefs, IB Tauris, London.

Kloppenborg, J.S., 2008, $Q$, the earliest gospel: An introduction to the original stories and sayings of Jesus, Westminster John Knox, Louisville.

König, A., 2009, Die evangelie is op die spel: Die verwarring oor die Bybel, en oor Jesus se lewe, sterwe en opstanding. 'n Alternatief op liberalisme en fundamentalisme, LuxVerbi.BM, Wellington.

Kraus, H.-J., 1969, Geschichte der historisch-kritischen Erforschung des Alten Testaments, Neukirchener Verlag, Neukirchen-Vluyn.

Le Roux, J.H., 1986, 'Johannes du Plessis as Bybelwetenskaplike', Theologia Evangelica (South Africa) 19, 15-35.

Lüdemann, G., 2000, Jesus after two thousand years: What he really said and did, SCM, London.

Luttikhuizen, G.P., 2006, De veelvormigheid van het vroegste Christendom, Damon, Budel.

Marguerat, D. \& Bourquin, Y., 1999, How to read Bible stories, SCM, London.

Noll, M.A., 1991, Between faith and criticism: Evangelicals, scholarship, and the Bible, Apollos, Leicester.

Painter, J., 2010, 'Johannine literature: The gospel and letters of John', in D.E. Aune (ed.), The Blackwell companion to the New Testament, pp. 344-372, WileyBlackwell, Chichester. doi: 10.1002/9781444318937.ch20

Primavesi, A., 2000, Sacred Gaia: Holistic theology and earth system science, Routledge, London. doi: 10.4324/9780203451786

Rogerson, J.W., 1984, Old Testament criticism in the nineteenth century: England and Germany, SPCK, London.

Schnelle, U., 1998, The history and theology of the New Testament writings, SCM, London.

Schröter, J., 2010, 'The gospel of Mark', in D.E. Aune (ed.), The Blackwell companion to the New Testament, pp. 272-295, Wiley-Blackwell, Chichester. doi: to the New Testament, pp.
10.1002/9781444318937.ch17

Shriver, G.E. (ed.), 1997, Dictionary of heresy trials in American Christianity, Greenwoord Press, Westport.

Spangenberg, I.J.J., 1985, 'Daniël 9: 'n Voorspelling van die kruisigingsdatum van Jesus Christus?', Nederduitse Gereformeerde Teologiese Tydskrif 26, 271-281.

Spangenberg, I.J.J., 1994, 'Paradigmaveranderinge in die Bybelwetenskappe: 'n Bydrae tot die gesprek tussen die Bybelwetenskappe en sistematiese teologie', Religion \& Theology 1, 144-184. doi: 10.1163/157430194X00141

Spangenberg, I.J.J., 1999, 'Die Suid-Afrikaanse navorsingsgeskiedenis van die boek Daniël en die eksegetiese spel', Old Testament Essays 12, 591-608.

Spangenberg, I.J.J., 2002, 'Hoe dink vandag se mense oor die Bybel?', Verbum et Ecclesia 23, 183-195.

Spangenberg, I.J.J., 2009, Jesus van Nasaret, Griffel Media, Cape Town.

Stanton, G., 2002, The gospels and Jesus, Oxford University Press, Oxford.

Suggit, J., 1997, The Gospel and the gospels, Celebration of Faith, Cape Town.

Sullivan, C., 2002, Rescuing Jesus from the Christians, Trinity, Harrisburg.

Theissen, G., 2003, The New Testament: An introduction, T \& T Clark, London.

Thierry, J.J., 1982, Korte geschiedenis van de tekst van het nieuwe testament, Kok, Kampen.

Thompson, R.P., 2010, 'Luke-Acts: The gospel of Luke and the acts of the Apostles', in D.E. Aune (ed.), The Blackwell companion to the New Testament, pp. 319-334, Wiley-Blackwell, Chichester. doi: 10.1002/9781444318937.ch19

Trocmé, E., 1997, The childhood of Christianity, SCM, London.

Van Aarde, A., 2001, Fatherless in Galilee: Jesus as child of God, Trinity Press, Harrisburg.

Van Gennep, F.O., 1989, Waarlijk opgestaan! Een discussie over de opstanding van Jezus Christus, Baarn, Ten Haave.

Vermes, G., 2001, The changing faces of Jesus, Penguin, London.

Vermes, G., 2008, The resurrection, Penguin, London.

Vorster, W.S., 1981, Wat is 'n evangelie?, NG Kerkboekhandel, Pretoria.

Walters, P., 2010, 'The synoptic problem', in D.E. Aune (ed.), The Blackwell companion to the New Testament, pp. 236-253, Wiley-Blackwell, Chichester. doi: 10.1002/9781444318937.ch15 